\title{
Seroprevalence of hepatitis B and C among domestic and healthcare waste handlers in
}

\section{Brazil}

\section{Authors:}

Marcos Paulo Gomes Mol${ }^{1}$, Jéssica Pereira Gonçalves ${ }^{2}$, Edvania Alves Silva ${ }^{2}$, Cristiane Faria de Oliveira Scarponi ${ }^{2}$, Dirceu Bartolomeu Greco ${ }^{3}$, Sandy Cairncross ${ }^{4}$, Leo Heller ${ }^{5}$

\section{$\underline{\text { Abstract }}$}

Infection with the hepatitis B and C viruses may occur through parenteral contact associated with infected body fluids, including injury with infected sharps. Collectors of domestic or healthcare wastes are potentially exposed to these infections. The aim of this paper is to investigate the risk factors associated with the prevalence of hepatitis $\mathrm{B}$ and $\mathrm{C}(\mathrm{HBV}$ and $\mathrm{HCV})$ infection of domestic and healthcare waste workers in Belo Horizonte, Brazil. A cross-sectional study of hepatitis B and C infection was conducted from November 2014 to January 2015, through blood sample collection and interviews about socio-demographic factors with 61 workers exposed to healthcare waste ("exposed") and 461 exposed only to domestic wastes ("unexposed"). The prevalence of Anti-HCV antibodies was $3.3 \%$ in "exposed" workers and $0.9 \%$ in "unexposed", and of AntiHBc was 9.8\% and 5.6\% in "exposed" and "unexposed" workers, respectively. Only 207 (44.9\%) of those exposed to domestic waste and $45(73.8 \%)$ of those handling healthcare waste were

\footnotetext{
${ }^{1}$ Fundação Ezequiel Dias / Universidade Federal de Minas Gerais. Belo Horizonte - MG / Brasil. Rua Conde Pereira Carneiro, 80. Gameleira. BH-MG. Brasil. CEP 30510-010. DPD.

${ }^{2}$ Fundação Ezequiel Dias. Belo Horizonte - MG / Brasil

${ }^{3}$ Faculdade de Medicina, Universidade Federal de Minas Gerais. Belo Horizonte - MG / Brasil

${ }^{4}$ London School of Hygiene and Tropical Medicine. London / United Kingdon

${ }^{5}$ Centro de Pesquisas René Rachou - Fundação Oswaldo Cruz. Belo Horizonte - MG / Brasil
} 
effectively immunized against HBV. Exposures to domestic waste and to healthcare wastes were associated with similar risks of infection with HBV. The risk of HCV infection was marginally higher among healthcare waste workers compared to domestic waste workers, probably because of needlestick accidents due to deficient sharps management systems. Immunization against hepatitis B and screening test to ensure the success of vaccination should be a condition for recruitment for both groups of waste workers.

Keywords: Hepatitis B, Hepatitis C, Cross-section, Healthcare waste, Domestic waste. 
Introduction

Hepatitis viruses cause liver inflammation which may lead to fibrosis, cirrhosis or liver cancer (BRAGA et al, 2004). The hepatitis B and C viruses (HBV and HCV) usually are transmitted by parenteral contact with infected body fluids, such as blood and semen. Transmission of either virus can be perinatal or percutaneous, and HBV is more commonly sexually transmittted than HCV (STEVENS and COYLE, 2000; WHO, 2015a). In particular, the parenteral route includes exposure to shared needles or syringes, to tattoos or piercings, to dental or other surgical procedures, and injury with infected sharps (PATEL, 2015; BRASIL, 2010). Lesion from sharps previously used on infected patients is associated with a risk of infection of $18-30 \%$ for $\mathrm{HBV}$, $1.8 \%$ for HCV and $0.3 \%$ for HIV (ALTER, 1995; PRUSS-USTUN et al., 2005; PURO et al., 2010, WHO, 2015b).

The global prevalence of $\mathrm{HCV}$ infection is estimated at around $2 \%$ or $3 \%$ of the population, implying that around 150 million people have this chronic infection worldwide. About 500,000 die each year due to liver problems resulting from HCV (WHO, 2015a; MARTINS et al., 2011). Regarding HBV, it is estimated that 240 million people are chronically infected around the world, defined by HBV surface antigen positivity in the last six months. More than 780,000 die every year from complications associated with HBV (NASCIMENTO et al., 2012; WHO, 2015a). 
HBV has been found in body secretions and excreta. However, the only proven vehicles of infection are blood and body fluids, semen and vaginal fluids (PURO et al., 2010; PATEL, 2015). Besid es, the virus shows environmental persistence and a very small amount is sufficient to cause infection. The number of infectious particles of HBV and HCV in infected blood can reach $10^{9}$ $\mathrm{ml}^{-1}$ and $10^{6} \mathrm{ml}^{-1}$, respectively (SATTAR et al., 2001).

Bond et al. (1981) and WHO (2015a) concluded that objects or surfaces that had contact with body fluids infected by HBV, including blood, plasma or serum, if not cleaned properly, could be a source of transmission of hepatitis B for more than 7 days. Besides, HBV concentration in clotted blood in the environment is usually high, increasing the risk of infection.

Domestic waste is similar to some types of healthcare wastes, in particular because it may include blood, faeces, secretions, and also used hygienic absorbents, dressings and syringes contaminated with potentially infective organisms (RUTALA and MAYHALL, 1992; CUSSIOL et al., 2006; BORG, 2007). Pathogenic microorganisms are present in domestic and healthcare wastes, suggesting that caution is needed in both waste management systems. Few health indicators are clearly presented to monitor the health protection of handler wastes, in particular related to pathogenic microorganisms presented in body fluids.

Thus, workers who collect domestic or healthcare wastes are potentially exposed to body fluids during their employment, and consequently to the potential presence of $\mathrm{HBV}$ and $\mathrm{HCV}$. Contact 
with these liquids may carry a risk of infection, especially when associated with needlestick accidents, favouring the entrance of the infections agent.

When comparing health risks of exposure to domestic and healthcare waste, it is not clear which type of waste carries a higher health risk through unprotected contact. Some literature reviews have indicated the importance of this question, but no conclusion is offered (TOOHER et al., 2005; CORRAO et al., 2013; MOL et al., 2015).

The aim of this paper is therefore to investigate the risk factors associated with hepatitis B and C infections for domestic and healthcare waste workers in Belo Horizonte municipality, Brazil. The implications for immunization policy are also discussed.

Methods

Data collection included collection of blood samples and of socio-demographic information gathered through an interview, for a cross-sectional study. The data collection occurred from November 2014 to January 2015. The research was carried out according to the Brazilian National Ethics Commission (CONEP/CNS) requirements and approved by the Research Ethics Committee of UFMG (18 June, 2014, protocol CAAE - 28018714.6.0000.5149).

Sample size calculation was based on the Kelsey model (DEAN et al., 2013) adopting the ratio of eight domestic waste workers for each healthcare waste worker. This ratio was adopted due to the 
small number of healthcare waste workers in the city where the study took place. The sample size required for $\mathrm{HCV}$ was also adopted because the requirement was larger than for HBV. The requirement was for 56 "exposed" workers (i.e. who handle healthcare wastes), and 444 "unexposed" workers (who handle domestic wastes).

95 healthcare waste workers and 800 domestic waste workers were invited to participate. Due to various circumstances, such as withdrawals and failure to arrive in time for interview, data were collected from 522 workers, 61 exposed to healthcare waste and 461 to domestic waste. Each worker was invited to participate after receiving an explanation about the study: those who agreed to participate signed the Consent Form. This was followed by blood sample collection and the socio-demographic interview. From among all workers who were able and willing to participate, the sample was selected by randomization.

The main inclusion criterion was the type of work activity: "exposed" subjects were those who handled healthcare wastes and "unexposed" were those who handled domestic wastes. There were no inclusion or exclusion criteria other than occupation. Thus, every worker exposed to wastes was eligible for inclusion, independent of exposure time and duration, age or gender.

Blood samples were collected by experienced nurses. Approximately $10 \mathrm{ml}$ of blood was collected from each participant. The tubes were centrifuged for serum separation before being sent for analysis. 
Every serum sample was screened for HBsAg marker, the first marker that appears in the course of infection with $\mathrm{HBV}$, and for Anti-HBc, that represents previous contact with this virus. Afterwards, all samples were tested for Anti-HBs, to identify immunity against HBV. Samples were also screened for Anti-HCV, to identify subjects with previous contact with HCV virus.

Serological tests used Architect i2000sr trials based on CHEMIFLEX technology, through chemoluminescence detection - a variation of immunoassay enzymatic principle (EIA). The samples were stored at $-10^{\circ} \mathrm{C}$ to $-40^{\circ} \mathrm{C}$, according to the manufacturer's instructions.

Interviews were applied by researchers trained for this activity. The socio-demographic questionnaire included personal characteristics, economics, occupation, occupational conditions, work accidents reported, type of waste handled, reports of potential health risk, immunization status, contact with fluids/wastes and social history including: sexual habits, alcohol and drug use, tattoos, piercings, blood transfusion and imprisonment history. These questions were used in multivariate models for outcomes analysis.

Data were analysed using R software, version 3.2.0. Fisher's Exact Test and the Chi-Square Test were used for categorical variables, and the Mann-Whitney Test for quantitative variables (AGRESTI, 2002; HOLLANDER and DOUGLAS, 1999). Confidence interval for odds ratio was adjusted for small samples when Fisher's Exact Test was used (JEWELL, 2004). The zeros in the contingency table were changed to 0.5 to enable confidence intervals to be calculated. 
$\underline{\text { Results }}$

Some characteristics of the subjects are presented in TABLE 1, according to the two exposure groups (domestic and healthcare). There were statistically significant differences between the groups for the variables gender, education level and household monthly income. Healthcare waste workers had higher income and higher percentage of advanced educational standard than the domestic waste workers. These differences did not affect the risk for hepatitis B or C infection. In general, exposed and unexposed subjects presented similar characteristics in several aspects.

TABLE 1 - Socio-demographic characteristics of study subjects.

\begin{tabular}{|c|c|c|c|c|}
\hline \multirow[b]{2}{*}{ Variable } & & \multicolumn{2}{|c|}{ Waste } & \multirow[b]{2}{*}{ p-value } \\
\hline & & $\begin{array}{c}\text { Domestic } \\
\text { N }(\%)\end{array}$ & $\begin{array}{c}\text { Healthcare } \\
\text { N (\%) }\end{array}$ & \\
\hline \multirow{2}{*}{ Gender } & Female & $106(23.0)$ & $6(9.8)$ & \multirow{2}{*}{$0.019^{1}$} \\
\hline & Male & $355(77.0)$ & $55(90.2)$ & \\
\hline \multirow{4}{*}{ Ethnic self-identification * } & White or Yellow & $69(15.0)$ & $14(23.0)$ & \multirow{4}{*}{$0.287^{2}$} \\
\hline & Dark, Brown & $216(47.0)$ & $29(47.5)$ & \\
\hline & Indigenous, Mixed race & $13(2.8)$ & $2(3.3)$ & \\
\hline & Black & $162(35.2)$ & $16(26.2)$ & \\
\hline \multirow{4}{*}{ Education Level } & Less than Basic Level & $8(1.7)$ & $0(0.0)$ & \multirow{4}{*}{$<0.001^{2}$} \\
\hline & Basic Level & $313(67.9)$ & $22(36.0)$ & \\
\hline & Medium Level & $137(29.7)$ & $39(63.9)$ & \\
\hline & Higher Education & $3(0.7)$ & $0(0.0)$ & \\
\hline \multirow{3}{*}{ Marital Status } & Single & $142(30.8)$ & $15(24.6)$ & \multirow{3}{*}{$0.059^{2}$} \\
\hline & Married, Stable Union & $293(63.6)$ & $46(75.4)$ & \\
\hline & Divorced, Widowed & $26(5.6)$ & $0(0.0)$ & \\
\hline Age (years) & Mean + SE & $36.05 \pm 0.47$ & $35.74 \pm 1.39$ & $0.740^{3}$ \\
\hline Household Monthly Income & Mean + SE & $1923.52 \pm 55.12$ & $2294.13 \pm 148.91$ & $0.002^{3}$ \\
\hline Years of current work (month) & Mean + SE & $21.9 \pm 1.5$ & $20.9 \pm 2.8$ & $0.392^{3}$ \\
\hline Years of last work (month) & Mean + SE & $75.6 \pm 4.7$ & $39.0 \pm 10.2$ & $0.538^{3}$ \\
\hline Individual Protection E quipment used & No & $1(0.2)$ & $0(0.0)$ & $1.000^{2}$ \\
\hline
\end{tabular}




\begin{tabular}{|c|c|c|c|c|}
\hline & Yes & $460(99.8)$ & $61(100.0)$ & \\
\hline \multirow{2}{*}{ Work accident reported (with wastes) } & No & $308(66.8)$ & $45(73.8)$ & \multirow{2}{*}{$0.275^{2}$} \\
\hline & Yes & $153(33.2)$ & $16(26.2)$ & \\
\hline \multirow{3}{*}{ Type of accident (last event) * } & Muscular lesion/fracture & $39(25.7)$ & $2(12.5)$ & \multirow{3}{*}{$0.303^{2}$} \\
\hline & Needlestick / cuts & $82(53.9)$ & $12(75.0)$ & \\
\hline & Traffic & $31(20.4)$ & $2(12.5)$ & \\
\hline \multirow{2}{*}{$\begin{array}{l}\text { Dripping or splashing during waste } \\
\text { collection * }\end{array}$} & No & $305(66.7)$ & $38(62.3)$ & \multirow{2}{*}{0.491} \\
\hline & Yes & $152(33.3)$ & $23(37.7)$ & \\
\hline \multirow{2}{*}{ Use of alcohol* } & No & $248(53.9)$ & $29(47.5)$ & \multirow{2}{*}{$0.349^{1}$} \\
\hline & Yes & $212(46.1)$ & $32(52.5)$ & \\
\hline \multirow{2}{*}{ Use of drugs* } & No & $340(79.1)$ & $48(81.4)$ & \multirow{2}{*}{$0.684^{1}$} \\
\hline & Yes & $90(20.9)$ & $11(18.6)$ & \\
\hline \multirow{2}{*}{ Extramarital sex relati ons (last year)* } & No & $277(85.8)$ & $40(81.6)$ & \multirow{2}{*}{$0.448^{1}$} \\
\hline & Yes & $46(14.2)$ & $9(18.4)$ & \\
\hline \multirow{2}{*}{ Sex without condom (last year)* } & No & $134(29.3)$ & $13(21.3)$ & \multirow{2}{*}{$0.196^{1}$} \\
\hline & Yes & $324(70.7)$ & $48(78.7)$ & \\
\hline \multirow{2}{*}{ Blood transfusion* } & No & $426(93.8)$ & $58(95.1)$ & \multirow{2}{*}{$1.000^{2}$} \\
\hline & Yes & $28(6.2)$ & $3(4.9)$ & \\
\hline \multirow{2}{*}{ Tattoos or piercings $*$} & No & $307(66.7)$ & $45(73.8)$ & \multirow{2}{*}{$0.270^{1}$} \\
\hline & Yes & $153(33.3)$ & $16(26.2)$ & \\
\hline \multirow{2}{*}{ History of imprisonment $*$} & No & $410(89.5)$ & $59(96.7)$ & \multirow{2}{*}{$0.102^{2}$} \\
\hline & Yes & $48(10.5)$ & $2(3.3)$ & \\
\hline
\end{tabular}

${ }^{1}$ Chi-Square Test, ${ }^{2}$ Fisher's Exact Test; ${ }^{3}$ Mann-Whitney Test. * Data for these variables are available for less than 461 subjects (Domestic) or 61 (Healthcare) either because question did not apply or subject did not answer.

Most subjects were male, $78.5 \%$ (410) versus $21.5 \%$ (112) female. The ethnicity declared by the majority of participants when asked about to classify themselves was black $34.2 \%$ (178) or dark/brown 47.0\% (245). Predominant education level was Basic, 64.2\% (335). Median age was 35 years, not much different from the mean for each of the exposure groups.

TABLE 2 presents the univariate analysis for both $\mathrm{HCV}$ and $\mathrm{HBV}$ (HBsAg and Anti-HBc) outcomes, according to the main socio-demographic characteristics of the study population. Statistically significant differences were: tattoo or piercing for HBsAg; and Educational Level, 
Age and Years of service for Anti-HBc. Years of service was the only variable associated with labour activities which also showed an association with an outcome. 
TABLE 2 - Univariate analysis for serology HCV, HBsAg and Anti-HBc per socio-demographics characteristics between groups exposed to wastes.

\begin{tabular}{|c|c|c|c|c|c|c|c|c|c|c|}
\hline \multicolumn{2}{|l|}{ Variables } & \multicolumn{3}{|c|}{$\mathrm{HCV}$} & \multicolumn{3}{|c|}{ HBsAg } & \multicolumn{3}{|c|}{ Anti-HBc } \\
\hline & & $(-)$ & $(+)$ & $\begin{array}{c}\mathrm{p}- \\
\text { value }\end{array}$ & $(-)$ & $(+)$ & $\begin{array}{c}\mathrm{p}- \\
\text { value }\end{array}$ & $(-)$ & $(+)$ & p-value \\
\hline Gender & $\begin{array}{l}\text { Female } \\
\text { Male }\end{array}$ & $\begin{array}{l}111 \\
(99.1) \\
405 \\
(98.8) \\
\end{array}$ & $\begin{array}{l}1 \\
(0.9) \\
5 \\
(1.2)\end{array}$ & $1.000^{2}$ & $\begin{array}{l}112 \\
(100.0) \\
407(99.3)\end{array}$ & $\begin{array}{l}0 \\
(0.0) \\
3 \\
(0.7)\end{array}$ & $1.000^{2}$ & $\begin{array}{l}104 \\
(92.9) \\
386 \\
(94.1)\end{array}$ & $\begin{array}{l}8(7.1) \\
24 \\
(5.9)\end{array}$ & $0.657^{1}$ \\
\hline Education Level & $\begin{array}{l}\text { Less than Basic Level } \\
\text { Basic Level } \\
\text { Medium Level } \\
\text { Higher Education }\end{array}$ & $\begin{array}{l}8(100.0) \\
331 \\
(98.8) \\
174 \\
(98.9) \\
3(100.0)\end{array}$ & $\begin{array}{l}0 \\
(0.0) \\
4 \\
(1.2) \\
2 \\
(1.1) \\
0 \\
(0.0)\end{array}$ & $1.000^{2}$ & $\begin{array}{l}8(100.0) \\
334(99.7) \\
174(98.9) \\
3(100.0)\end{array}$ & $\begin{array}{l}0 \\
(0.0) \\
1 \\
(0.3) \\
2 \\
(1.1) \\
0 \\
(0.0)\end{array}$ & $0.319^{2}$ & $\begin{array}{l}7(87.5) \\
310 \\
(92.5) \\
171 \\
(97.2) \\
2(66.7)\end{array}$ & $\begin{array}{l}1 \\
(12.5) \\
25 \\
(7.5) \\
5(2.8) \\
1 \\
(33.3)\end{array}$ & $0.020^{2}$ \\
\hline Marital Status & $\begin{array}{l}\text { Single } \\
\text { Married, Stable Union } \\
\text { Divorced, Widowed }\end{array}$ & $\begin{array}{l}154 \\
(98.1) \\
336 \\
(99.1) \\
26 \\
(100.0)\end{array}$ & $\begin{array}{l}3 \\
(1.9) \\
3 \\
(0.9) \\
0 \\
(0.0)\end{array}$ & $0.198^{2}$ & $\begin{array}{l}155(98.7) \\
338(99.7) \\
26(100.0)\end{array}$ & $\begin{array}{l}2 \\
(1.3) \\
1 \\
(0.3) \\
0 \\
(0.0)\end{array}$ & $0.345^{2}$ & $\begin{array}{l}146 \\
(93.0) \\
318 \\
(93.8) \\
26 \\
(100.0)\end{array}$ & $\begin{array}{l}11 \\
(7.0) \\
21 \\
(6.2) \\
0(0.0)\end{array}$ & $0.502^{2}$ \\
\hline Age (years old) & $\begin{array}{l}\text { No reactive } \\
(\mathrm{Mean}+\mathrm{SE}) \\
\text { Reactive }(\text { Mean }+\mathrm{SE})\end{array}$ & $\begin{array}{l}36.02 \\
35.33\end{array}$ & $\begin{array}{l}0.45 \\
2.68\end{array}$ & $0.972^{3}$ & $\begin{array}{l}36.05 \pm \\
29.33 \pm\end{array}$ & $\begin{array}{l}0.45 \\
4.06\end{array}$ & $0.235^{3}$ & $\begin{array}{l}35.5 \\
42.9\end{array}$ & $\begin{array}{l}=0.45 \\
=1.69\end{array}$ & $<0.001^{3}$ \\
\hline Household Monthly Income ( $R \$)$ & $\begin{array}{l}\text { No reactive } \\
(\text { Mean }+\mathrm{SE}) \\
\text { Reactive }(\text { Mean }+\mathrm{SE})\end{array}$ & $\begin{array}{r}1972.34 \\
1493.33\end{array}$ & $\begin{array}{l}=52.32 \\
362.83\end{array}$ & $0.187^{3}$ & $\begin{array}{l}1966.50= \\
2023.33 \pm\end{array}$ & $\begin{array}{l}52.00 \\
989.05\end{array}$ & $0.757^{3}$ & $\begin{array}{r}1950.9 \\
2209.9\end{array}$ & $\begin{array}{l} \pm 51.96 \\
=290.72\end{array}$ & $0.390^{3}$ \\
\hline Work accident with wastes & No & $\begin{array}{c}348 \\
(98.6)\end{array}$ & $\begin{array}{c}5 \\
(1.4)\end{array}$ & $0.669^{2}$ & $352(99.7)$ & $\begin{array}{l}1 \\
(0.3)\end{array}$ & $0.246^{2}$ & $\begin{array}{l}332 \\
(94.1)\end{array}$ & $\begin{array}{l}21 \\
(5.9)\end{array}$ & $0.846^{1}$ \\
\hline
\end{tabular}




\begin{tabular}{|c|c|c|c|c|c|c|c|c|c|c|}
\hline reported & Yes & $\begin{array}{c}168 \\
(99.4)\end{array}$ & $\begin{array}{c}1 \\
(0.6)\end{array}$ & & $167(98.8)$ & $\begin{array}{l}2 \\
(1.2)\end{array}$ & & $\begin{array}{l}158 \\
(93.5)\end{array}$ & $\begin{array}{l}11 \\
(6.5)\end{array}$ & \\
\hline Dripping or splashing during & No & 338 & 5 & \multirow[b]{2}{*}{$0.669^{2}$} & $341(99.4)$ & & \multirow[b]{2}{*}{$1.000^{2}$} & 320 & & \multirow[b]{2}{*}{$0.566^{1}$} \\
\hline waste collection* & Yes & $\begin{array}{c}(98.5) \\
174 \\
(99.4)\end{array}$ & $\begin{array}{c}(1.5) \\
1 \\
(0.6)\end{array}$ & & $174(99.4)$ & $\begin{array}{l}(0.6) \\
1 \\
(0.6)\end{array}$ & & $\begin{array}{l}(93.3) \\
166 \\
(94.9)\end{array}$ & $\begin{array}{l}(6.7) \\
9(5.1)\end{array}$ & \\
\hline \multirow[t]{2}{*}{$\begin{array}{l}\text { Years of current work (in } \\
\text { months) }\end{array}$} & $\begin{array}{l}\text { No reactive } \\
(\mathrm{Mean}+\mathrm{SE})\end{array}$ & \multicolumn{2}{|c|}{$21.86 \pm 1.40$} & \multirow{2}{*}{$0.872^{3}$} & \multicolumn{2}{|c|}{$21.81 \pm 1.39$} & $0.640^{3}$ & \multicolumn{2}{|c|}{$20.09 \pm 1.22$} & $0.001^{3}$ \\
\hline & Reactive (Mean+SE) & \multicolumn{2}{|c|}{$12.83 \pm 2.65$} & & \multicolumn{2}{|c|}{$11.67 \pm 0.33$} & & \multicolumn{2}{|c|}{$47.22 \pm 12.07$} & \\
\hline \multirow[t]{2}{*}{ Years of last work (in months) } & $\begin{array}{l}\text { No reactive } \\
(\text { Mean }+\mathrm{SE})\end{array}$ & \multicolumn{2}{|c|}{$75.44 \pm 4.71$} & \multirow[t]{2}{*}{$0.191^{3}$} & \multicolumn{2}{|c|}{$75.22 \pm 4.72$} & $0.903^{3}$ & \multicolumn{2}{|c|}{$73.75 \pm 4.77$} & $0.197^{3}$ \\
\hline & Reactive (Mean+SE) & \multicolumn{2}{|c|}{$21.00 \pm 3.00$} & & \multicolumn{2}{|c|}{$48.50 \pm 0.5$} & & 100.08 & 24.00 & \\
\hline & No & 385 & 3 & & $387(99.7)$ & 1 & & 364 & 24 & \\
\hline Use of drugs* & & (99.2) & $(0.8)$ & $0106^{2}$ & & $(0.3)$ & $0110^{2}$ & $(93.8)$ & $(6.2)$ & $0819^{1}$ \\
\hline & Yes & $98(97.0)$ & $\begin{array}{c}3 \\
(3.0) \\
\end{array}$ & & $99(98.0)$ & $\begin{array}{l}2 \\
(2.0)\end{array}$ & & $94(93.1)$ & $7(6.9)$ & \\
\hline Sex without condom* & No & 146 & 1 & & $145(98.6)$ & 2 & & 138 & $9(6.1)$ & \\
\hline & & $(99.3)$ & $(0.7)$ & $1.000^{2}$ & & $(1.4)$ & $0.195^{2}$ & $(93.9)$ & & $1.000^{1}$ \\
\hline & Yes & $\begin{array}{c}367 \\
(98.7)\end{array}$ & $\begin{array}{c}5 \\
(1.3)\end{array}$ & & $371(99.7)$ & $\begin{array}{l}1 \\
(0.3)\end{array}$ & & $\begin{array}{l}349 \\
(93.8)\end{array}$ & $\begin{array}{l}23 \\
(6.2)\end{array}$ & \\
\hline & No & 478 & 6 & & $481(99.4)$ & 3 & & 455 & 29 & \\
\hline Blood transfusion* & & $(98.8)$ & $(1.2)$ & $1000^{2}$ & & $(0.6)$ & $1000^{2}$ & $(94.0)$ & $(6.0)$ & $0.709^{2}$ \\
\hline & Yes & $\begin{array}{c}31 \\
(100.0)\end{array}$ & $\begin{array}{c}0 \\
(0.0)\end{array}$ & & $31(100.0)$ & $\begin{array}{l}0 \\
(0.0)\end{array}$ & & & $2(6.5)$ & \\
\hline & No & 349 & 3 & & 352 & 0 & & 329 & 23 & \\
\hline Tattoo or piercing * & & $(99.1)$ & $(0.9)$ & $0395^{2}$ & $(100.0)$ & $(0.0)$ & $0034^{2}$ & $(93.5)$ & $(6.5)$ & $0609^{1}$ \\
\hline 1alloo or plercing & Yes & $\begin{array}{c}166 \\
(98.2)\end{array}$ & $\begin{array}{c}3 \\
(1.8)\end{array}$ & $0.395^{2}$ & $166(98.2)$ & $\begin{array}{l}3 \\
(1.8)\end{array}$ & $0.034^{2}$ & $\begin{array}{l}160 \\
(94.7)\end{array}$ & $9(5.3)$ & $0.699^{1}$ \\
\hline & No & 465 & 4 & & $466(99.4)$ & 3 & & 437 & 32 & \\
\hline History of imnrisonment* & & $(99.1)$ & $(0.9)$ & $0106^{2}$ & & $(0.6)$ & $1000^{2}$ & $(93.2)$ & $(6.8)$ & $0061^{2}$ \\
\hline пistory of imprisoniment & Yes & $48(96.0)$ & $\begin{array}{c}2 \\
(4.0)\end{array}$ & $0.100^{-2}$ & $50(100.0)$ & $\begin{array}{l}0 \\
(0.0)\end{array}$ & $1.000^{2}$ & $\begin{array}{l}50 \\
(1000)\end{array}$ & $0(0.0)$ & $0.061^{2}$ \\
\hline
\end{tabular}

${ }^{1}$ Chi-Square Test, ${ }^{2}$ Fisher's Exact Test; ${ }^{3}$ Mann-Whitney Test. * Data for these variables are available for less than 461 subjects (Domestic) or 61 (Healthcare) because question did not apply or subject did not answer. 
Prevalence of Anti-HCV was 3.3\% among healthcare waste workers and $0.9 \%$ for the domestic waste group, and prevalence of Anti-HBc was 9.8\% and 5.6\% respectively. Thus previous contact with $\mathrm{HBV}$ or HCV was more common among those exposed to healthcare wastes than to domestic wastes. However the differences were not statistically significative. Anti-HBs, a marker for previous vaccination, was found in $73.8 \%$ of healthcare waste workers, as compared to only $44.9 \%$ in those exposed to domestic wastes.

Multivariate models of HCV and Anti-HBc are presented in TABLES 3 and 4. The variable waste exposure was always retained in the models, just like those significant or marginally significant variables, to support the understanding of occupational risk of hepatitis. There was no multivariate model for HBsAg serology due to the insufficient number of positive results.

TABLE 3 - Multivariate model for HCV outcome in waste exposed workers.

\begin{tabular}{lccc}
\hline \multicolumn{1}{c}{ Variables } & p-value & OR & $\mathbf{9 5 \%}$ CI \\
\hline Waste $=$ domestic & - & 1.00 & - \\
Waste $=$ healthcare & 0.071 & 5.42 & {$[0.86 ; 33.97]$} \\
Individual Equipment Protection used currently = No & - & 1.00 & - \\
Individual Equipment Protection used currently = Yes & 0.025 & 0.07 & {$[0.01 ; 0.71]$} \\
History of imprisonment $=$ No & - & 1.00 & - \\
History of imprisonment $=$ Yes & 0.046 & 6.54 & {$[1.04 ; 41.22]$} \\
\hline \hline \multicolumn{2}{c}{ Pseudo R R $^{2}$ (Nagelkerke) = 19.62\%; p-value (Hosmer Lemeshow) $=0.965$} & &
\end{tabular}


TABLE 4 - Multivariate model for Anti-HBc outcome in waste exposed workers.

\begin{tabular}{lccc}
\hline \multicolumn{1}{c}{ Variables } & p-value & OR & $\mathbf{9 5 \%}$ CI \\
\hline Waste $=$ domestic & - & 1.00 & - \\
Waste $=$ heathcare & 0.302 & 1.77 & {$[0.60 ; 5.27]$} \\
Age & 0.008 & 1.06 & {$[1.02 ; 1.11]$} \\
Current working time (years) & 0.006 & 1.17 & {$[1.05 ; 1.30]$} \\
Extramarital sex relations (last year) $=$ No & - & 1.00 & - \\
Extramarital sex relations (last year) $=$ Yes & 0.068 & 2.62 & {$[0.93 ; 7.36]$} \\
\hline \hline
\end{tabular}

Pseudo R ${ }^{2}$ (Nagelkerke) = 15.14\%; p-value (Hosmer Lemeshow) $=0.502$

Regarding vaccination history, TABLE 5 depicts workers recall on past hepatitis B vaccination and the Anti-HBs actual results.

TABLE 5 - Reports of vaccination against HBV versus serology results of Anti-HBs (effective immunization).

\begin{tabular}{lllllll}
\hline \multirow{2}{*}{ Variables } & & \multicolumn{4}{c}{ Waste } & \multirow{2}{*}{ p-value } \\
\cline { 2 - 6 } & & Domestic & Healthcare & \\
\hline Have you been immunized against & No & 25 & $6.8 \%$ & 0 & $0.0 \%$ & \multirow{2}{*}{$0.035^{2}$} \\
hepatitis B? * & Yes & 340 & $93.2 \%$ & 60 & $100.0 \%$ & \\
\hline Anti-Hbs** & No & 254 & $55.1 \%$ & 16 & $26.2 \%$ & \multirow{2}{*}{$* 0.001^{1}$} \\
& Yes & 207 & $44.9 \%$ & 45 & $73.8 \%$ & \\
\hline
\end{tabular}

${ }^{1}$ Chi-Square Test, ${ }^{2}$ Fisher's Exact Test.

* Data for these variables are available for less than 461 subjects (Domestic) or 61 (Healthcare) because question did not apply or subject did not answer.

** O.R. $=3.45(95 \%$ CI $1.90-6.28)$.

\section{Discussion}

The multivariate model of HCV indicated three possible factors that could be associated with the outcomes. Two were for occupational exposure: use of individual protection equipment, and domestic or healthcare exposure. The third independent factor was history of imprisonment. 
Healthcare waste exposure presented higher risk than domestic waste exposure, and, although the difference is only marginally significant it should not be ignored. The individual protection equipment use represented a protective factor as $\mathrm{HCV}$ seropositivity was less likely among workers who reported its regular use. Non-use suggests HCV infection risk for both groups of workers, independent of type of waste. History of imprisonment was significantly different between exposure groups with a high odds ratio, suggesting an independent factor of waste exposure that can explain the risks of HCV infection among waste collectors. Approximately $10.0 \%$ of all waste collectors reported history of imprisonment, according TABLE 2.

History of imprisonment was associated to high prevalence of hepatitis B and C, in particular due to sexual activities without condom and sharing infected equipment, including injected drugs (DOLAN et al., 2010; GIDDING el al., 2015; HEIMER et al., 2015).

About waste exposure, similar analysis showed in Ethiopia, for $\mathrm{HCV}$, detection in only one $(1.0 \%)$ worker exposed to healthcare waste and none $(0.0 \%)$ in unexposed, suggesting a HCV seroprevalence higher among the exposed, although few serologic results (ANAGAW et al., 2012). Another study, by Franka et al. (2009), also indicated a higher risk for those exposed to healthcare waste compared to the unexposed group of workers, including 600 Libyan workers, 300 healthcare waste collectors and 300 who collect common part of healthcare waste. The common part of hospital waste is different from urban domestic wastes because the urban type usually includes body fluids mixed to the wastes. The HCV was detected in eight (2.7\%) and none $(0.0 \%)$, respectively, healthcare waste exposed and unexposed $(\mathrm{p}<0.005)$. 
The association between healthcare waste exposure and HCV infection risk suggests a higher risk from exposure to healthcare waste, as found on serologic results of Belo Horizonte waste workers and other studies (FRANKA et al., 2009; ANAGAW et al., 2012). In particular, large numbers of sharps accidents were reported: that increases the risk of infections, according to many similar studies (POULSEN et al., 1995; DOMINGO and NADAL, 2009; LAZZARI and REIS, 2011; SILVA et al., 2014; VIEIRA et al., 2011; VELLOSO et al., 1997; PORTA et al., 2009; GIANCOTTI et al., 2014; BLENKHARN and ODD, 2008; AN et al., 1999).

The multivariate model for Anti-HBc did not suggest that the type of waste exposed to was associated with the outcome. The association with age and length of service were statistically significant, with higher risk associated with more years of service. Another marginally significant association was with reported extramarital sex relations in the last year. However both groups of workers may be susceptible to HBV with increased risk over time.

The length of time collecting domestic or healthcare waste was also found, in other studies, to be associated with higher probability of infection, and consequently, higher HBV prevalence. Shiferaw et al. (2011) found Odds Ratio (OR): 10 (95\% CI: 3.7 - 32.1) for the age group between 40 to 49 years, compared with younger workers. Rachiotis et al. (2012) found the workers' ages were associated with infection prevalence, pointing out $\mathrm{OR}=5.22(95 \% \mathrm{CI}: 1.35-20.1)$ for older workers when compared to younger. Dounias et al (2005) found higher Anti-HBc prevalence in older Greek workers, and Tsovili et al. (2014), indicated that the mean age of those who tested 
positive for Anti-HBc was significantly higher in workers belonging to the group "exposed" to waste when compared to those "unexposed", and the length of service (in years) collecting wastes suggested higher Anti-HBc occurrence among the more exposed.

Studies comparing domestic and healthcare waste collectors' exposure showed divergences. Ferreira et al. (1999) investigated Anti-HBc serology in 186 Brazilian workers, 31 healthcare waste workers and 155 domestic waste workers. They found Anti-HBc in $12.9 \%$ of healthcare waste workers and $14.2 \%$ in domestic waste workers, $\mathrm{OR}=0.9(95 \% \mathrm{CI}: 0.24-3.0)$. Thus the risk of infection with HBV was similar in these two groups of workers.

Nevertheless, the study in Ethiopia by Shiferaw et al. (2011) involved 252 workers, 126 exposed to healthcare waste and 126 to common part of hospital wastes in three public hospitals. No workers had been immunized against HBV prior to the study. HBsAg was found in eight (6.3\%) healthcare waste workers and one $(0.8 \%)$ exposed to common part of hospital wastes, with an OR $=8(95 \%$ CI: $1.02-63.02 ; \mathrm{p}=0.01)$. Prevalence of HBV was higher in healthcare waste exposed workers, although the prevalence of $\mathrm{HBsAg}$ was $7 \%$ and Anti-HBc was $45-53 \%$ in the population of Ethiopia at that time.

A similar study evaluated 200 workers of an Ethiopian hospital, 100 healthcare waste collectors and 100 exposed to common part of hospital wastes. Antibodies to HBV were detected in six $(6.0 \%)$ healthcare waste workers and in one (1.0\%) exposed to common part of hospital wastes, 
giving $\mathrm{OR}=6.3 ; \mathrm{p}=0.04$, suggesting an association between high infection risk and the type of waste collected, but was unable to prove it because of the small sample (ANAGAW et al., 2012).

A Libyan study included 600 workers (300 exposed to healthcare waste, 300 to common part of hospital wastes). Antibodies to HBV were detected in seven (2.3\%) "exposed" and one $(0.3 \%)$ "unexposed". The odds ratio found for HBV infection was $\mathrm{OR}=7.14(\mathrm{p}<0.04)$, evidencing a significantly higher HBV prevalence in workers exposed to healthcare waste than to those exposed to common part of hospital wastes (FRANKA et al., 2009).

The Ethiopian and Libyan studies suggested higher HBV infection risk in exposed than unexposed, focussing exclusively on hospital waste workers. The common part of hospital wastes are usually different from urban domestic wastes, not least because they often contain body fluids, which would explain the difference found. Both healthcare and domestic wastes seem to carry similar risk of infection for collection workers. This is true of HBV and of HCV.

There were no significant differences in the presence of $\mathrm{HBsAg}$ and anti-HBc between healthcare and domestic waste workers of Belo Horizonte. Some researchers argue that healthcare wastes have greater risks than domestic waste (GERSHON et al., 2005; TOOHER et al., 2005), but others maintain that the risks are similar (BORG, 2007; COSTA E SILVA et al., 2011; CUSSIOL et al., 2006; FERREIRA et al., 1999; MÜHLICH et al., 2003; ZANON, 2002). Healthcare wastes and domestic wastes both demand a secure management system because of some dangerous 
characteristics, including biological and accident hazards, especially the presence of body fluids mixed in the wastes.

\section{$\underline{\text { Infection risks due to waste exposure }}$}

An investigative study after a needlestick accident used an RNA test to demonstrate HCV infection was carried out in relation to a subject who reported no drug use, blood transfusion, surgery, tattoos, piercings or other similar recent procedure. Serology for HBV and HIV were negative (LIBOIS et al., 2005). Another study offered little information about the risk of hepatitis infection from mucocutaneous contact, but reported one case of HCV seroconversion after body fluids splashed in the eye of a subject, and another case of HIV and HCV infection arising from the same exposure route (SARTORI et al., 1993).

Contact with body fluids or needlestick accidents represent potential routes for HBV infection. The high perceived prevalence of reported needlestick accidents, $53.9 \%$ in domestic waste workers and $75.0 \%$ in healthcare waste workers, shows a worrying exposure context that minor cuts and punctures are dangerous. Lack of a statistically significant difference between reported answers for the two groups indicate that both do dangerous work, with frequent occurrence of this type of accident.

Shiferaw et al. (2011) reported a high proportion of positive Anti-HBc associated with the occurrence of blood or body fluids splashing in the eyes, mouth or nose: $17(48.6 \%)$ of 35 workers 
were initially positive, but after needlestick accidents this rose to $15(60 \%)$ out of 25 . Tsovili et al. (2014) found six (28.6\%) Anti-HBc positives associated with needlestick accident reported, vs. one (3.4\%) unexposed to wastes with a similar accident. Rachiotis et al. (2012) found a Relative Risk (RR) of $2.64(95 \% \mathrm{CI}=1.01-6.96)$ for the association between reported needlestick accidents and HBV positivity. Luksamijarulkul et al. (2008) suggested needlestick accidents were associated with seropositivity for $\mathrm{HBV}$ in workers exposed to domestic wastes $(\mathrm{OR}=4.21$, p $<0.0001$ ). Finally, El-Gilany et al. (2013), pointed out that individual protection equipment was used only by a minority of Egyptian waste workers, $4.2 \%, 3.3 \%$ and $0.8 \%$ for gloves, boots and masks, respectively. According to the workers this protection equipment was unavailable. Whatever the cause, it culminated with the reported $50.8 \%$ prevalence of needlestick accidents.

Other studies specifically investigated urban domestic waste collectors, but did not include healthcare waste exposure. Various comparison groups of workers were adopted in these studies, including gardeners, office workers, and workers performing other activities with no waste contact. Higher prevalence of hepatitis infection was found in those exposed to domestic wastes versus unexposed to wastes, corroborating the hypothesis that domestic waste exposure also carries a risk of hepatitis B or C infection (MARIOLIS et al., 2006; SQUERI et al., 2006; RACHIOTIS et al., 2012; LUKSAMIJARULKUL et al., 2008; DOUNIAS et al., 2005; TSOVILI et al., 2014; EL-GILANY et al., 2013).

Immunization 
The workers' immunization status is presented in TABLE 5, indicating that $400(86.8 \%)$ workers (340 exposed to domestic waste and 60 to healthcare waste) reported being vaccinated against hepatitis B. However, the serology showed that only 252 (54.7\%) workers (207 exposed to domestic waste and 45 to healthcare waste) were effectively immunized. Those who are exposed to wastes but not effectively immunized are at high risk of infection. Many are not aware of the real risk of their becoming infected during routine work. In Brazil, since March 2010, the HBV vaccine is distributed for free by the Unified Health System for vulnerable groups, which includes domestic and healthcare waste collectors.

Similar studies in Libya have pointed out that only a minority $(21.0 \%)$ of waste workers were vaccinated against HBV (FRANKA et al., 2009). Squeri et al. (2006) found that of $183(56.0 \%)$ Italian workers considered protected against HBV due to the presence of Anti-HBs, only 98 were vaccinated and thus the other 85 have had previous contact with HBV.

Jack et al. (1999), Tooher et al. (2005), Gershon et al. (2005) and Zuckerman (2006) showed that vaccination against hepatitis B is an important measure to protect workers exposed to wastes, both healthcare waste and domestic waste, and should be given before exposure starts. Immunization is critical to the prevention of hepatitis B, in particular those workers most exposed to wastes. There is currently no available vaccine against hepatitis $\mathrm{C}$.

\section{Conclusion}


The health risk of exposure to wastes, whether domestic or from healthcare waste management activity, is increasingly supported by scientific evidence. The search for specific indicators to prove such an association is a challenge to future research, and also to programme managers seeking to protect their staff and the public. It is a fact that risk for both hepatitis B and C infection is associated with contact with solid wastes, particularly sharps, and that immunization against $\mathrm{HBV}$ is recommended as the chief preventive measure.

The handling of healthcare wastes carries a risk of infection with HBV, similar to the risk of handling domestic wastes. There was a marginally significant difference in HCV infection risk and higher infection risks from exposure to healthcare waste than to domestic waste, probably due to needlestick accidents which points to an ineffective sharps management system. Studies performed in hospitals have also compared healthcare waste and the common part of hospital wastes. The common part of hospital wastes is different from urban domestic wastes because the urban type usually includes body fluids mixed to the wastes. Both healthcare and domestic waste exposures represent risk for infection with hepatitis viruses.

In this context, it does not seem prudent to emphasise difference in health risks for healthcare waste compared to domestic waste. It is preferable to evaluate carefully the waste management system of healthcare waste generators and the characteristics of each type of waste according to associated hazards, to provide appropriate segregation and consequently, minimize risk of workers exposed to the wastes. The main risk pointed out for present discussion is associated with needlestick accidents, and it is well-known that healthcare waste should be properly segregated 
and packed before collection. Failures in separating these wastes increase accident risks, and the waste generators are responsible for proper management of this stage. Difference between risks may indicate inappropriate management of one type or the other, rather than a difference in the waste characteristics.

The individual protection equipment uses are fundamental to health protection of waste handlers and not using were associated to higher risk of infection by hepatitis $\mathrm{C}$, according multivariate model presented. Therefore, waste managers company should increase supervisory to ensure that effective measures are taken to protect the health and quality life of these workers. Workers should use their right to demand a safety work conditions, in particular the appropriate individual equipment protection offering during all work time.

This study depicts a critical situation with many workers exercising their occupational activities without the protection of immunization against hepatitis B. Adequate immunization against hepatitis B is a right and must be available to all workers exposed to waste, both healthcare and domestic. AntiHBs serology should also be mandatory to ensure the success of vaccination. 


\section{$\underline{\text { References: }}$}

Agresti A. (2002). Categorical Data Analysis. Second Edition. New York: Wiley.

Alter MJ. (1995). Epidemiology of hepatitis C in the West. Sem Liver Disease; 15:5-14.

An H, Englehardt J, Fleming L, Bean J. (1999) Occupational health and safety amongst municipal solid waste workers in Florida. Waste Manag Res. 17:369.

Anagaw B, Shiferaw Y, Belyhun Y, Erku W, Biadgelegn F, Moges B, et al. (2012). Seroprevalence of hepatitis B and C viruses among medical waste handlers at Gondar town Health institutions, Northwest Ethiopia. BMC Research Notes, v.5.

Blenkharn JI, Odd C. (2008). Sharps Injuries in Healthcare Waste Handlers. Ann. Occup. Hyg., Vol.52, No.4, pp.281-286.

Bond WW, Favero MS, Petersen NJ, Gravelle CR, Ebert JW, Maynard JE. (1981). Survival of hepatitis B virus after drying and storage for one week. Lancet; 8219:550-551.

Borg MA. (2007). Clinical waste disposal - getting the facts right. Journal of Hospital Infection. Dez.v.65, 178-179.

Braga WSM, Brasil LM, Souza RAB, Melo MA, Rosas MDG, Castilho MC, Fonseca JCF. (2004). Prevalência de infecção pelos vírus da hepatite B e da hepatite Delta em Lábrea, rio Purus, 
Estado do Amazonas [Prevalence of hepatitis B virus and hepatitis Delta virus infections in Labrea, Purus river, Amazonas State]. Epidemiologia e Serviços de saúde; 13:35-46.

Brasil, Ministério da Saúde. (2010). Secretaria de Vigilância em Saúde. Departamento de Vigilância Epidemiológica. Doenças infecciosas e parasitárias: guia de bolso. [Infectious deaseses and parasitic: pocket guide] 8. ed. Brasília: Ministério da Saúde.

Corrao CRN, Del Cimmuto A, Marzuillo C, Paparo E, La Torre G. (2013). Association between Waste Management and HBV among Solid Municipal Waste Workers: A Systematic Review and Meta-Analysis of Observational Studies. The Scientific World Journal, v. 2013, 2013.

Costa e Silva CAM, Campos JC, Ferreira JA, Miguel MAL, Quintaes BR. (2011). Caracterização microbiológica de lixiviados gerados por resíduos sólidos domiciliares e de serviços de saúde da cidade do Rio de Janeiro [Microbiological characterization of leachate from domestic and hospital solid wastes from Rio de Janeiro city]. Engenharia Sanitária e Ambiental. v. 16, n. 2, Abr/jun 2011, p. 127-132.

Cussiol NAM, Rocha GHT, Lange LC. (2006). Quantificação dos resíduos potencialmente infectantes presentes nos resíduos sólidos urbanos da regional sul de Belo Horizonte, MG, Brasil [Gravimetric characterization of potentially infectious material in urban solid waste in southern Belo Horizonte, Minas Gerais State, Brazil]. Cad. Saúde Pública, Rio de Janeiro, v.22. n.6, 1183 1191.

Dean AG, Sullivan KM, Soe MM. (2013). OpenEpi: Open Source Epidemiologic Statistics for Public Health, Versão. www.OpenEpi.com (accessed November 11, 2013). 
Dolan K, Teutsch S, Scheuer N, Levy M, Rawlinson W, Kaldor J, Lloyd A, Haber P. (2010). Incidence and risk for acute hepatitis $\mathrm{C}$ infection during imprisonment in Australia. Eur $J$ Epidemiol. 25:143-148.

Domingo JL, Nadal M. (2009). Domestic waste composting facilities: A review of human health risks. Environment International 35, 382-389.

Dounias G, Kypraiou E, Rachiotis G, Tsovili E, Kostopoulos S. (2005). Prevalence of hepatitis B virus markers in municipal solid waste workers in Keratsini (Greece). Occupational Medicine, v.55, n. $1,60-63$.

El-Gilany AH, Elwafa HSA, El-Bestar SF, Elsayed Zaki M. (2013). Prevalence of Hepatitis C Virus Antibodies among Municipal Solid Waste Collectors in Mansoura, Egypt. Occup. Med. Health Aff. 1, 6 .

FerreiraJA, Tambellini AT, Silva CLP, Guimaraens MAAM. (1999). Hepatitis B Morbidity in Municipal and Hospital Waste Collection Workers in the City of Rio de Janeiro. Infection Control and Hospital Epidemiology, v.20, n.9, 591-592.

Franka E, El-Zoka AH, Hussein AH, Elbakosh MM, Arafa AK, Ghenghesh KS. (2009).Hepatitis B virus and hepatitis C virus in medical waste handlers in Tripoli, Libya. Journal of Hospital Infection, v.72, n.3, p.258-261.

Gershon RRM, Mitchell C, Sherman MF, Vlahov D, Lears MK, Felknor S, et al. (2005). Hepatitis B vaccination in correctional health care workers. Am. J. Infect. Control, v.33, n.9, p.510-518. 
Giancotti GM, Haeffner R, Solheid NLS, Miranda FMD, Sarquis LMM. (2014). Caracterização das vítimas e dos acidentes de trabalho com material biológico atendidas em um hospital público do Paraná, 2012 [Characterization of accidents at work with biological material and their victims treated at a public hospital in Paraná, Brazil, 2012]. Epidemiol. Serv. Saúde, Brasília, 23(2):337346, abr-jun.

Gidding HF, Mahajan D, Reekie J, Lloyd AR, Dwyer DE, Butler T. (2015). Hepatitis B immunity in Australia: a comparison of national and prisoner population serosurveys. Epidemiol. Infect., $143,2813-2821$.

Heimer R, Levina OS, Osipenko V, Ruiz MS, Sergeyev B, Sirotkin AV, Vyshemirskaya I. (2015). Impact of incarceration experiences on reported HIV status and associated risk behaviours and disease comorbidities. The European Journal of Public Health. 1089-1094. DOI: http://dx.doi.org/10.1093/eurpub/ckv157

Hollander M, Douglas AW. (1999). Nonparametric Statistical Methods. New York: John Wiley \& Sons.

Jack AD, Hall AJ, Maine N, Mendy M, Whittle HC. (1999). What level of hepatitis B antibody is protective? J Infect Dis. Feb;179(2):489-92.

Jewell, NP. (2004). Statistics for Epidemiology. New York: Chapman \& Hall /CRC.

Lazzari MA, Reis CB. (2011). Os coletores de lixo urbano no município de Dourados (MS) e sua percepção sobre os riscos biológicos em seu processo de trabalho [The perception of urban 
garbage collectors of Dourados, in the state of Mato Grosso do Sul, regarding the biological risks involved in their work routine]. Ciência \& Saúde Coletiva, 16(8), 3437-3442.

Libois A, Fumero E, Castro P, Nomdedeu M, Cruceta A, Gatell JM, Garcia F. (2005). Transmission of Hepatitis C Virus by Discarded-Needle Injury. Clinical Infectious Diseases CID. 41(1 July); p;129.

Luksamijarulkul P, Sujirarat D, Charupoonphol P. (2008). Risk behaviors, occupational risk and seroprevalence of hepatitis B and A infections among public cleansing workers of Bangkok Metropolis. Hepatitis Monthly, v.8, n.1, 35-40.

Mariolis A, Mihas C, Magaziotou I, Alevizos A, Gizlis V, Papathanasiou M, et al. (2006). Seroepidemiological study of viral hepatitis among workers of the Cleaning Department of the Municipality of Vyronas: Preliminary results of a single centre study. Public Health, v.120, n. 11,1088-1089.

Martins T, Narciso-Schiavon JL, Schiavon LL. (2011). Epidemiologia da infecção pelo vírus da hepatite C. [Epidemiology of hepatitis C virus infection]. Revista da Associação Médica Brasileira. 57:107-112.

Mol MPG, Greco DB, Cairncross S, Heller L. (2015). Hepatitis B and C in household and health services solid waste workers. Cadernos de Saúde Publica. Rio de Janeiro, 31 Sup: S295-S300.

Mühlich M, Scherrer M, Daschner FD. (2003). Comparison of infectious waste management in European hospitals. Journal Hosp. Infection. v.55, 260-268. 
Nascimento PP, Pinto SGS, Pereira ICP, Bomfim MRQ, Grisotto MAG, Monteiro SG, Figueiredo PMS. (2012). Perfil epidemiológico dos marcadores sorológicos para vírus da hepatite B dos pacientes atendidos em um laboratório público [Epidemiological profile of serological markers for hepatitis B patients treated in a public laboratory]. Revista da Sociedade Brasileira de Clínica Médica. São Paulo - SP. 10:495-498.

Patel S. (2015). Hepatitis. South African Pharmaceutical Journal. Vol 82. N.6.

Porta D, Milani S, Lazzarino AI, Perucci CA, Forastiere F. (2009). Systematic review of epidemiological studies on health effects associated with management of solid waste. Environmental Health 8(60).

Poulsen OM, Breum NO, Ebbehoj N, Hansen AM, Ivens UI, Lelieveld D, Malmros P, Matthiasen L, Nielsen BH, Nielsen EM, Schibye B, Skov T, Stenbaek EI, Wilkins CK. (1995). Collection of domestic waste. Review of occupational health problems and their possible causes. The Science of the Total Environment 170, 1-19.

Pruss-Üstun A, Rapiti E, Hutin Y. (2005). Estimating the global burden of disease attributable to contaminated sharps injuries among health care workers. American Journal of Industrial Hygiene, 48(6):482-490.

Puro V, De Carli G, Segata A, Piccini G, Argentero PA, Signorini L, Daglio M, Penna C, Marchegiano P, Miniero M, Cinti G, Tavanti L, Maggiore A, Sossai D, Micheloni G. (2010). Update on the subject of epidemiology of blood-transmitted occupational infections. Giornale Italiano di Medicina del Lavoro ed Ergonomia, 32(3):235-239. 
Rachiotis G, Papagiannis D, Markas D, Thanasias E, Dounias G, Hadjichristodoulou C. (2012). Hepatitis B virus infection and waste collection: Prevalence, risk factors, and infection pathway. American Journal of Industrial Medicine, v.55, n.7, p.650-655.

Rutala WA, Mayhall CG. (1992). Medical waste. Infection Control of Hospital Epidemiology. $13: 38 \mathrm{e} 48$.

Sartori M, Laterra G, Aglietta M, Manzin A, Navino C, Verzetti G. (1993). Transmission of hepatitis C via blood splash into conjuctiva. Scand J Infect Dis; 25:270-271;

Sattar SA, Tetro J, Springthorpe VS, Giulivi A.. (2001). Preventing the spread of hepatitis B and C viruses: Where are germicides relevant? American Journal of Infection Control. 29:187-197.

Shiferaw Y, Abebe T, Mihret A. (2011). Hepatitis B virus infection among medical waste handlers in Addis Ababa, Ethiopia.(Short Report)(Report). BMC Research Notes, v.4,p.479.

Silva DF, Sperling EV, Barros RTV. (2014). Avaliação do gerenciamento dos resíduos de serviços de saúde em municípios da região metropolitana de Belo Horizonte (Brasil) [Evaluation of health care wastes management in the metropolitan region of Belo Horizonte (Brazil)]. Engenharia Sanitária e Ambiental. v.19 n.3; 251-262,jul/set.

Squeri R, Fauci VL, Sindoni L, Cannavo G, Spagnolo EV. (2006). Study on hepatitis B and C serologic status among municipal solid waste workers in Messina (Italy). Journal of Preventive Medicine and Hygiene, v.47,p.110-113. 
Stevens AB, Coyle PV. (2000). Hepatitis C virus: an important occupational hazard? Occup. Med. Vol.50, No.6, 377-382.

Tooher R, Griffin T, Shute E, Maddern G.. (2005). Vaccinations for waste-handling workers. A review of the literature. Waste Manage. Res., v.23, n.1, 79-86.

Tsovili E, Rachiotis G, Symvoulakis EK, Thanasias E, Giannisopoulou O, Papagiannis D, Eleftheriou A, Hadjichristodoulou C. (2014). Municipal waste collectors and hepatitis B and C virus infection: a cross-sectional study. Le Infezioni in Medicina, n. 4, 271-276.

Velloso MP, Santos EM, Anjos LA. (1997). Processo de trabalho e acidentes de trabalho em coletores de lixo domiciliar na cidade do Rio de Janeiro, Brasil [The labor process and workrelated accidents among garbage collectors in Rio de Janeiro, Brazil]. Cad. Saúde Públ., Rio de Janeiro, 13(4), 693-700.

Vieira M, Padilha MI, Pinheiro RDC. (2011). Análise dos acidentes com material biológico em trabalhadores da saúde [Analysis of accidents with organic material in health workers]. Rev. Latino-Am. Enfermagem. 19(2). Mar-Abr.

Who, World Health Organization. What is hepatites? [homepage on the internet], July 2015a. Acessed on 16th November, 2015. Available from: http://www.who.int/features/qa/76/en/

Who, World Health Organization. Health-care waste. [homepage on the internet], November 2015. Acessed on 16th November, 2015b. Available from: http://www.who.int/mediacentre/factsheets/fs253/en/ 
Zanon, U. (2002) As teorias da origem das doenças e a suposta periculosidade do lixo hospitalar. In: Eigenheer, E. Lixo Hospitalar: Ficção Legal ou Realidade Sanitária. SEMADS-Governo do Rio de Janeiro-RJ.

Zuckerman JN. (2006). Protective efficacy, immunotherapeutic potential, and safety of hepatitis B vaccines. J Med Virol. Feb;78(2):169-77. 